\title{
Letter to the Editor: Measurement of Pyruvate Carboxylase Activity in Amniotic Fluid Cells
}

\author{
GERALD L. FELDMAN AND BARRY WOLF
}

Department of Human Genetics and Pediatrics, Medical College of Virginia, Richmond, Virginia, USA

\begin{abstract}
We regret that we were unaware of Drs. Hansen and Christensen's previous publication of the measurement of pyruvate carboxylase activity in amniotic fluid cells at the time we performed

our experiments and published our data. We are gratified that our results agree so closely.

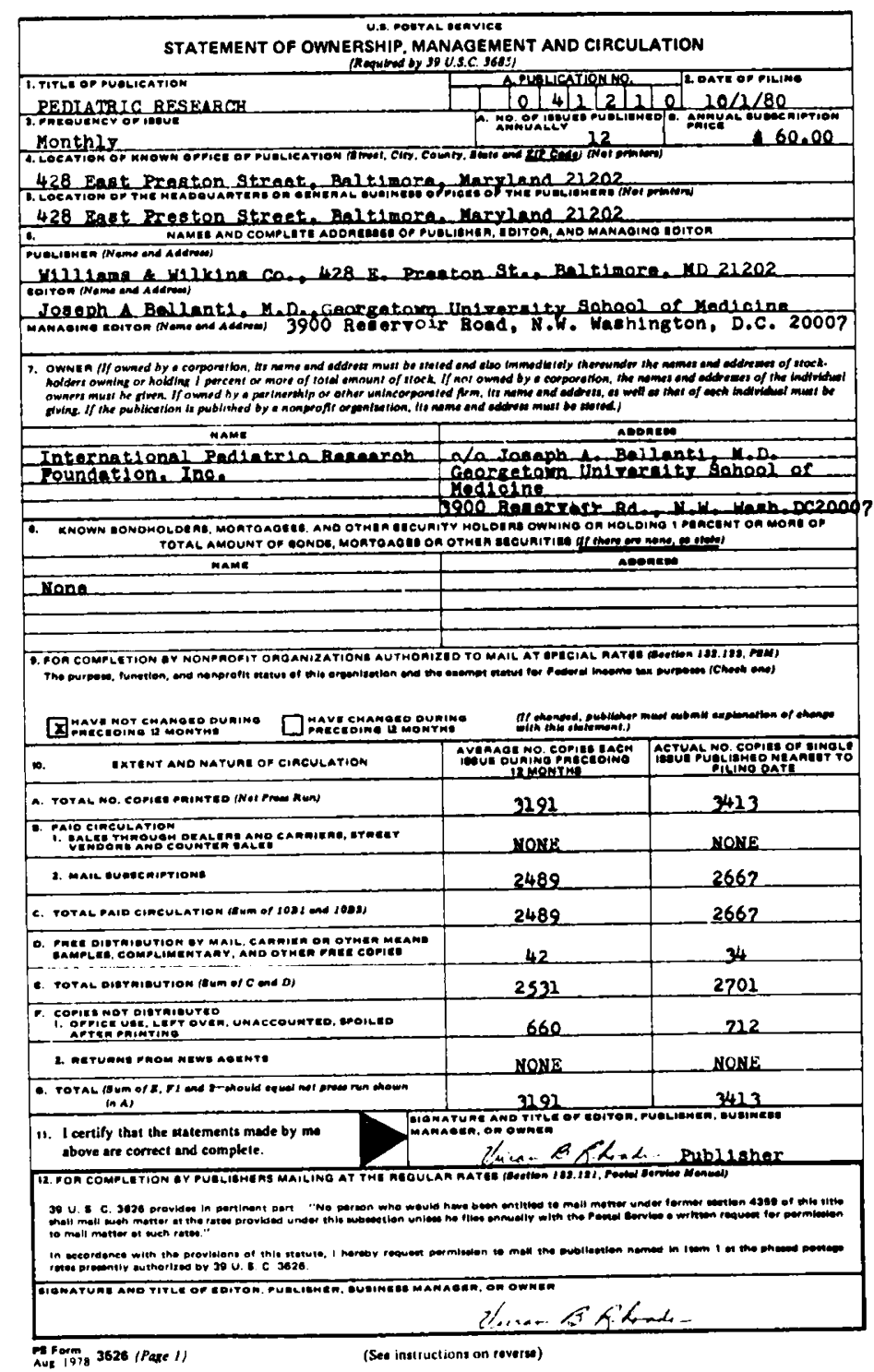

